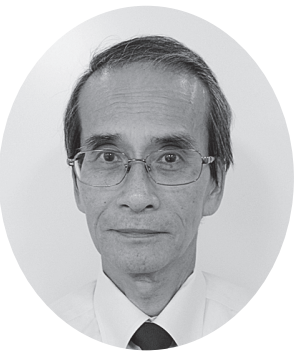

榎本 清志*

\begin{abstract}
Journal of The Japan Institute of Light Metals, Vol. 65, No. 9 (2015), 472-477
\end{abstract}
(C) 2015 The Japan Institute of Light Metals

\title{
Magnesium alloys for aircraft applications
}

\author{
Kiyoshi ENOMOTO*
}

Keywords: magnesium alloy, aircraft

\section{1.はじめに}

航空機の構造用材料としては, 20 世紀初頭より主として アルミニウム合金が使われてきたが, 最近はボーイング787 やエアバス $\mathrm{A} 350$ に見られるように, さらなる性能向上およ び軽量化をねらって炭素繊維強化複合材料 (CFRP) の使用 量が大幅に増大し, 構造重量の半分程度を占めている。

しかしながら， Al-Li合金が適用される動きもあり， CFRP 使用が今後も大幅に続くとは必ずしも言えず，金属材料も使 われ続けるのは間違いない。

一方，マグネシウムは比重が 1.74 でアルミニウムの $2 / 3$ と 構造用金属材料の中で最も軽量であり, 航空機構造用材料と して，大きな可能性を有しており，歴史的にも航空機構造へ 適用されたこともある。

本稿では, マグネシウム合金の航空機構造適用の歴史およ び新しいマグネシウム合金に関する取り組みについて解説す る。

\section{2. マグネシウム合金の航空機構造適用の歴史}

マグネシウム合金が最初に航空機部品へ適用されたのは, 1927 年北イタリアで, 水上飛行艇サンタ・マリア号のエン ジンブロック，オイルパンなどの鋳物部品である ${ }^{1)} 。 1930$ 年 代にはドイツの Focke Wulfの主要構造の一部にマグネシウム 合金板, 鍛造品, 鋳造品が $630 \mathrm{~kg}$ 使われた ${ }^{2)}$ 。

1940 年代になると, Lockheed F-80C 戦闘機一機の全機構造 を試験的にマグネシウム合金で製造することも行われた ${ }^{3)} 。$ 1 機で最もマグネシウム合金が適用されたのは図 1 に示す米 国の戦略爆撃機Convair B-36で, 全体で8.6トンものマグネ シウム合金が適用され, 機体, 翼, 尾翼部に 3.4 トンのマ グネシウム合金板材が使用された ${ }^{1)}$ 。アルミニウム合金に
比べて 4.5 トンの軽量化を実現したということで, 常に軽量 化が求められる航空機にとって, 魅力的な材料であること は間違いない。1950年代にはソ連において爆撃機TU-95MS に $1550 \mathrm{~kg}$ のマグネシウムが使用された ${ }^{3)}$ 。日本においては 1940 年に図 2 に示す高研機キ78（研三）において発動機架に マグネシウム合金の一体構造としたので，アルミニウム合金 に比べて半分程度の重量になった。また，1950年代には富 士重工業が米国ビーチクラフト社のライセンス生産により図 3 に示す T-34Aメンター練習機を生産していたが, 舵面にマ グネシウム合金が適用されていた ${ }^{2)}$ 。

その後, マグネシウム合金の耐食性の問題や価格高騰があ り，徐々にアルミニウム合金に置き換わって適用量が減って きた。現在航空機に適用されているのは, 振動減衰特性を活 かして, 図4に示すようなへリコプタ, 固定翼機のトランス ミッションケースやギアボックス等のケーシング等一部に限 られている4)。しかし, 強度上および耐食性, さらには耐火 性の問題を克服すれば, 航空機の構造部材への適用は十分考 えられる。

世界的に見ると, 航空機用鋳造マグネシウム合金の開発 は，主として英国の Magnesium Elektron Limited社で行われ， 図 5 に示すように強度, 耐熱性, 耐食性の向上が図られてき た2)。

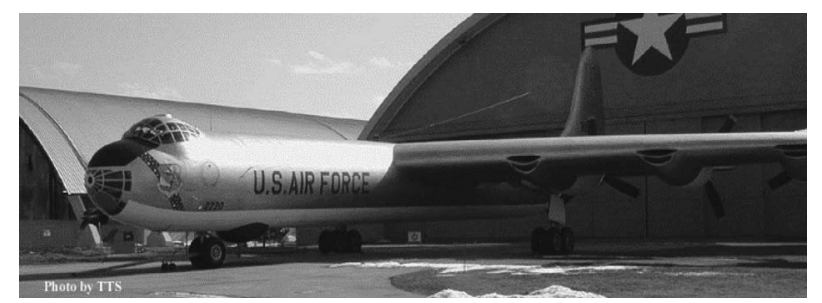

図 1 Convair B-36

\footnotetext{
*一般財団法人素形材センター 次世代材料技術室＼cjkstart航空機材料技術部（（１05-0011 東京都港区芝公園 3-5-8 機械振興会館） Aircraft Materials Engineering Division, RIMCOF Research Center of Advanced Metals and Composites, SOKEIZAI CENTER (Kikai Shinko Bldg., 3-5-8 Shibakoen, Minato-ku, Tokyo 105-0011) E-mail: enomoto@sokeizai.or.jp

受付日：平成27年5月1日＼cjkstart受理日：平成27年6月24日
} 


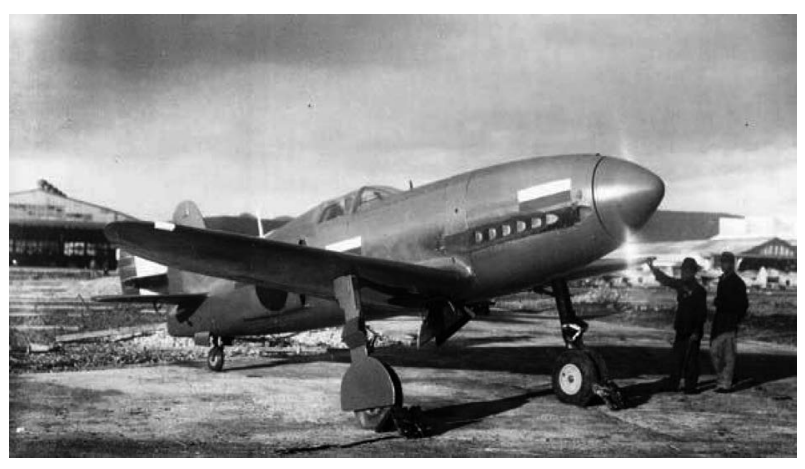

図2 高研機キ 78

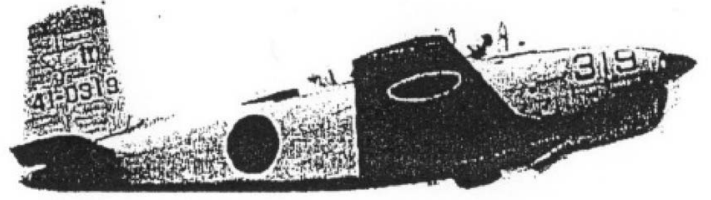

図3 T-34Aメンター

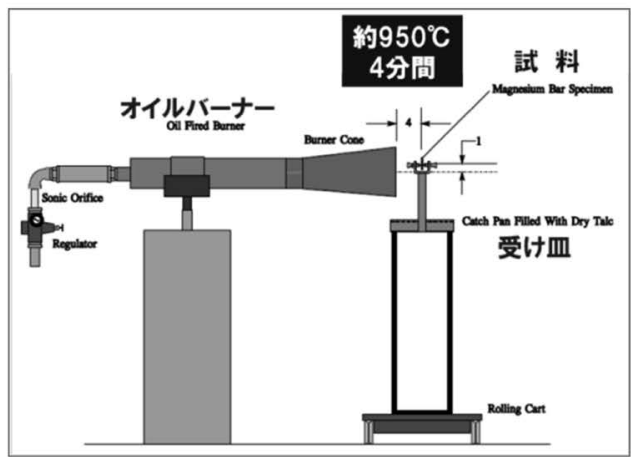

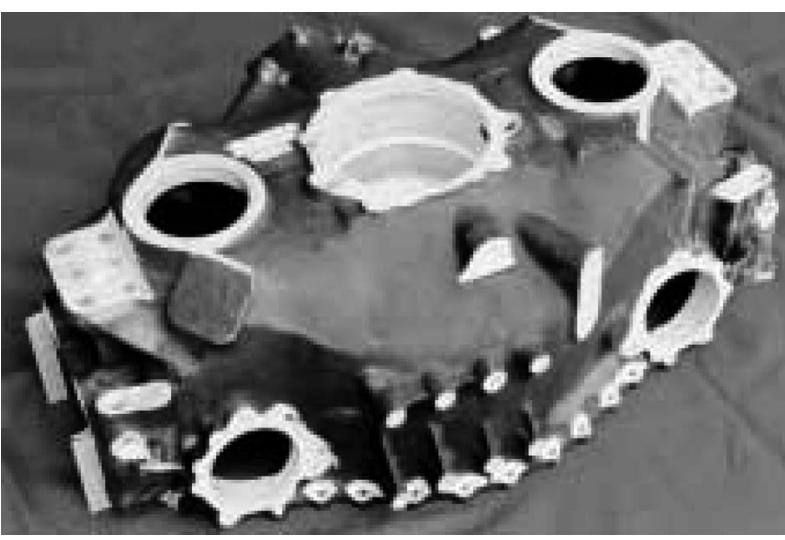

図4 ヘリコプタ用トランスミッションケース

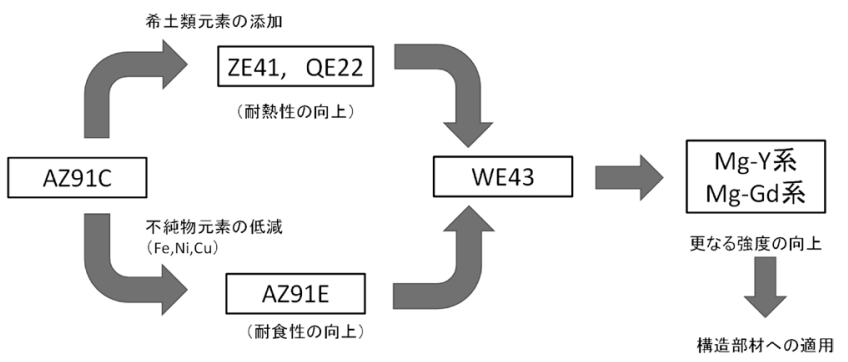

図5 マグネシウム鋳造合金開発の流れ

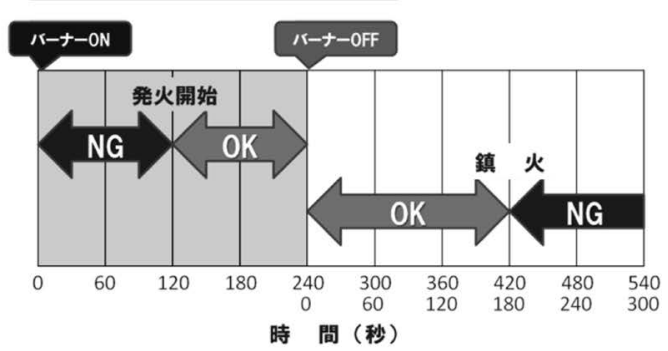

試験後の重量減は10\%以下

図6 FAA マグネシウム耐火試験

\section{3. マグネシウム合金の耐火性に関する動き}

マグネシウム合金は耐火性の観点から，航空機内部への適 用がアメリカ連邦航空局（FAA）により禁止されていた。し かし，1990年代後半に独立行政法人産業技術総合研究所に おいてマグネシウム合金にカルシウムを添加することによ り，発火温度の上昇が報告されている。その後, 英国や韓国 においても耐火性が向上したマグネシウム合金が開発され た。FAAでも図6に示す試験をクリアすれば，機内での適用 が認められる状況にあり ${ }^{5)}$ ，マグネシウム合金の航空機への 適用に関しては追い風になっていると言える。

\section{4. 世界の航空機へのマグネシウム合金開発の動き}

欧州，北米，オーストラリア，中国，韓国等海外ではマグ ネシウムを戦略材料に位置づけ，航空機だけではなく自動車 等もターゲットに公的資金により精力的に研究開発を進めて
いる。

韓国の鉄鋼大手メーカのPOSCO ではマグネシウム精錬工 場はもとより自動車向けにマグネシウム板材の製造を始めて いる。2000年には韓国の生産技術研究院（KITECH）で，市 販マグネシウム合金に $\mathrm{CaO}$ を $1 \mathrm{mass} \%$ 程度添加し発火温度の 向上と湯流れ性も向上する「ECOマグネシウム」を開発した。 発火温度は $620 \sim 660^{\circ} \mathrm{C}$ 程度とのこと。2012年に米国ボーイ ング社は韓国知識経済部と「ECOマグネシウム」を含めて 素材・部品分野の包括的協力に向けた了解覚書（MOU）を 締結した ${ }^{6)}$ 。

欧州ではマグネシウム合金を用いることにより，アル ミニウム構造に比べて $35 \%$ の軽量化を狙いAEROMAG (Aeronautical Application of Wrought Magnesium) プロジェク トが実施された。期間は2005年から 2008 年で，EADS，工 アバス, Magnesium Elektron Limited 社等 21 機関が参加し, AZ31, WE43 等の材料で構造部材を試作してアルミニウム合 
表 1 研究開発体制

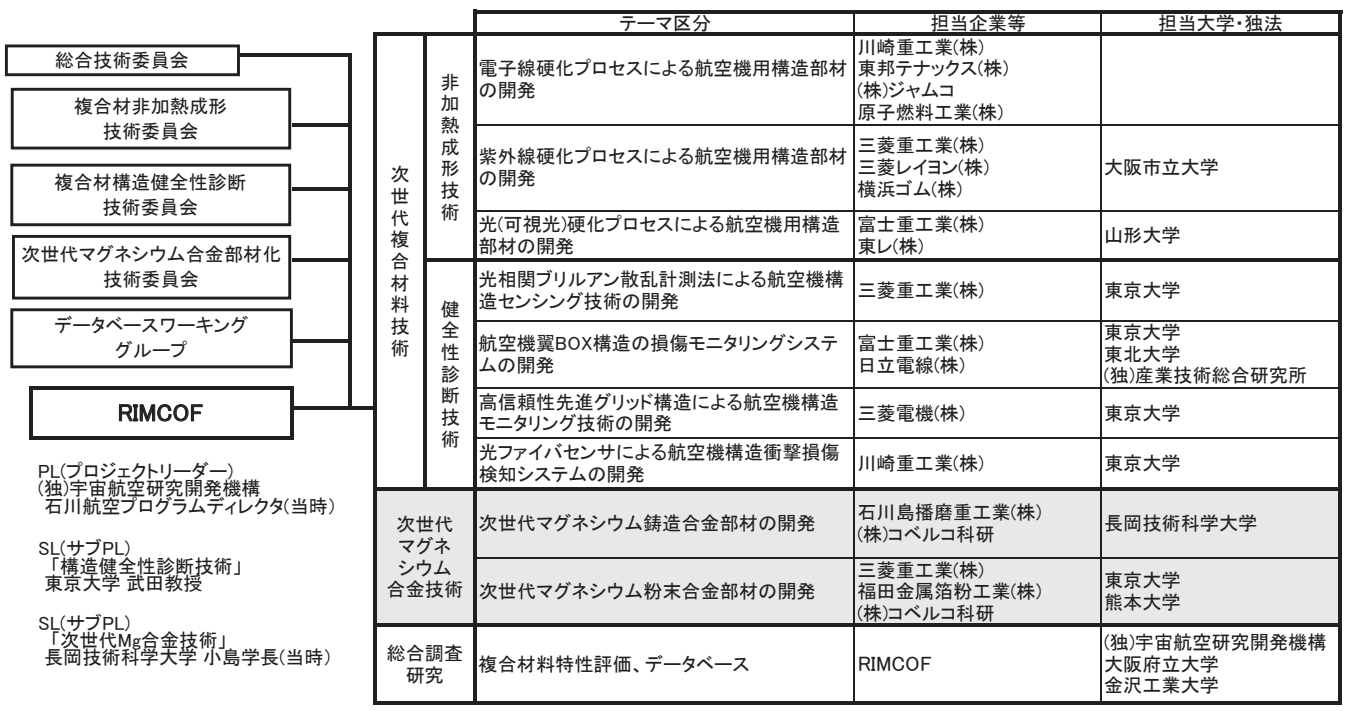

金と比較する各種試験を行った。FSW（Friction Stir Welding） やLBW（Laser Beam Welding）も行い, APU室の外板をスト レッチ成形して試作し，マグネシウム合金の構造部材成立性 を確認している7)。

また，時期的には重なるが，やはり欧州において MagForming (Development of New Magnesium Forming Technologies for the Aeronautics Industry）プロジェクトが 実施された。期間は2006年から 2009 年でEADS，エアバ ス, Magnesium Elektron Limited 社等 12 機関が参加している。

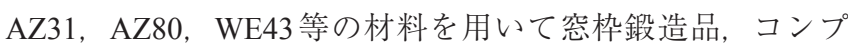
レッサインペラ鍛造品, 超塑性成形ドア, 深絞り成形アンテ ナサポート等を試作して，マグネシウム合金の成形技術のレ ベルアップを狙った。こちらのプロジェクトは部品レベル でマグネシウム合金を適用するための成形技術の開発であ る $^{8)}$

前述したようにFAAでは耐火試験をクリアすれば，航 空機内への適用が認められることとなったが, Magnesium Elektronはマグネシウム合金の航空機用座席への適用を 2014

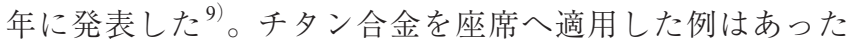
が，マグネシウム合金は初めてである。

\section{5. 日本におけるマグネシウム合金の研究開発}

欧米では 1950 年〜1980年代に急速凝固による高強度マグ ネシウム合金の開発が行われたが，その後わが国において， 1990 年代に東北大学金属材料研究所の増本らにより $\mathrm{Mg}-\mathrm{Al}$ Ca系や Mg-TM-RE（TM: 遷移金属）系のアモルファス合金 が開発されたが，実用化には至らなかった ${ }^{10)}$ 。

その後1999〜2003年に実施された文部科学省特定領域研 究 (B)「高性能マグネシウムの新展開」において研究開発 が広範囲に実施され，飛躍的な成果が得られた。熊本大学 の河村らは, Mg-Y-Zn 合金において液体急冷法で作成した 合金を固化成形し，濃度変調を伴った新奇な長周期積層構 造（以下LPSO構造という）を有するとともに耐力 $600 \mathrm{MPa}$, 伸び $5 \%$ を達成している。また，長岡技術科学大学の鎌土ら は，各種の合金組成により，アルミニウム合金と同程度の耐 熱特性が得られることを示した ${ }^{1)}$ 。

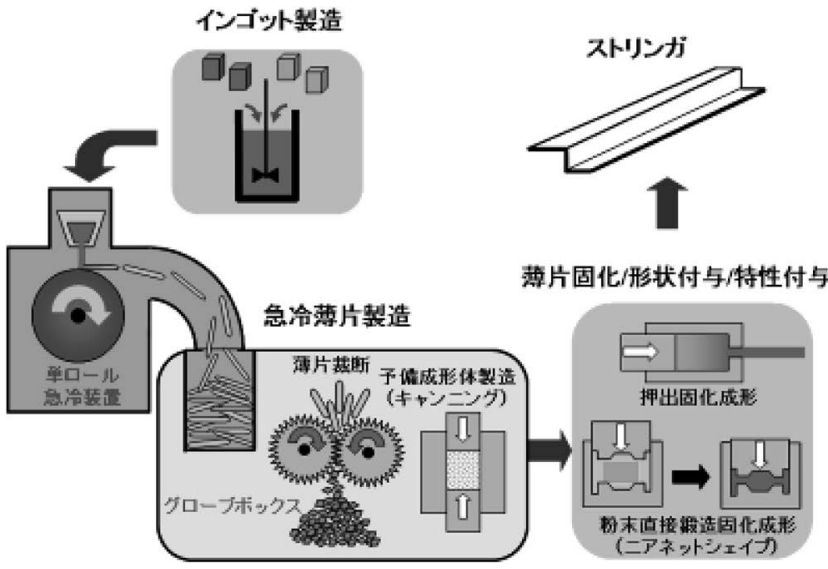

図7 マグネシウム粉末合金製造プロセス

これら大学の研究成果を踏まえて, 次世代金属・複合材料 研究開発協会（現 素形材センター）では, 経済産業省の民 間航空機基盤プログラム「次世代航空機用構造部材創製・加 工技術開発」の 1 テーマとして 2003 年度〜2007年度の 5 年間， 次世代マグネシウム合金製造技術の研究開発を実施した。

研究開発体制を表 1 に示すが，前述した熊本大学の河村ら の「次世代マグネシウム粉末合金部材の開発」と長岡技術科 学大学の鎌土らによる「次世代マグネシウム鋳造合金部材の 開発」の2テーマで, 大学の研究室レベルの成果を実用化す ることをねらい，企業と連携して実施した。

「次世代マグネシウム粉末合金部材の開発」においては $\mathrm{Mg}-\mathrm{Zn}-\mathrm{Y}$ を基本組成として急冷凝固により強度向上と耐食 性向上を狙った。マグネシウム合金は活性金属であるため, 大学で実施したガスアトマイズ法では，粉末粒子が細かくな ると爆発の危険性があり工業化するには問題であった。そこ で図7に製造プロセスを示すが，単ロール法を採用すること により急冷薄片作製技術を確立し，安全に高性能合金製造が 可能となった。図8に今回作製したマグネシウム合金薄片と 市販アルミニウム粉末の爆発燃焼試験結果を示す。マグネシ ウム薄片の爆発下限濃度が $800 \mathrm{~g} / \mathrm{m}^{3}$ であったのに対し，アル ミニウム粉末は $140 \mathrm{~g} / \mathrm{m}^{3}$ であり, 安全性が確認された。急冷 薄片製造装置を図9に示すが, 薄片製造後は裁断, 封缶, 押 


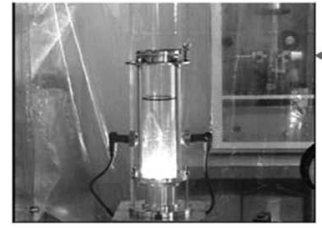

緩やかな燃焼
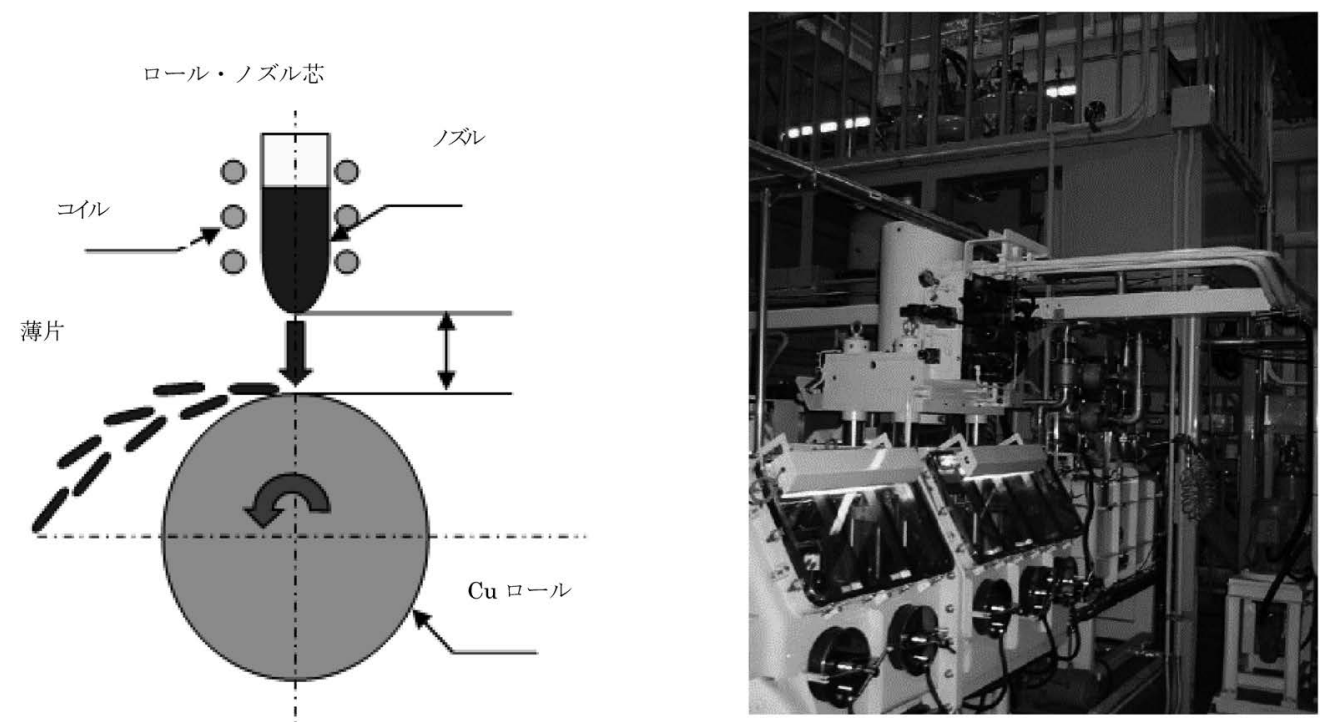

図9急冷薄片作製の概略図および装置外観

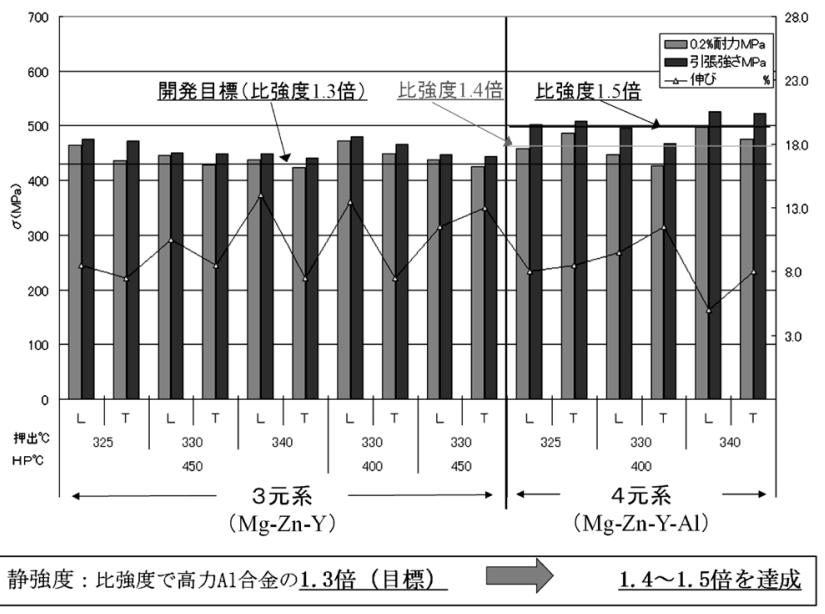

図10 マグネシウム粉末合金の比強度

出等の固化成形を行う。目標は7075アルミニウム合金材の 1.3 倍の比強度と同等の耐食性を有する合金の開発とした。 プロジェクトを進めていく中で, $\mathrm{Mg}-\mathrm{Zn}-\mathrm{Y}$ に機械的特性を 維持しつつ，耐食性を向上させる第四添加元素を検討し，Al が効果的であることを明らかにした。結果として，図10に 示すように比強度は目標であるアルミニウム合金の 1.3 倍を

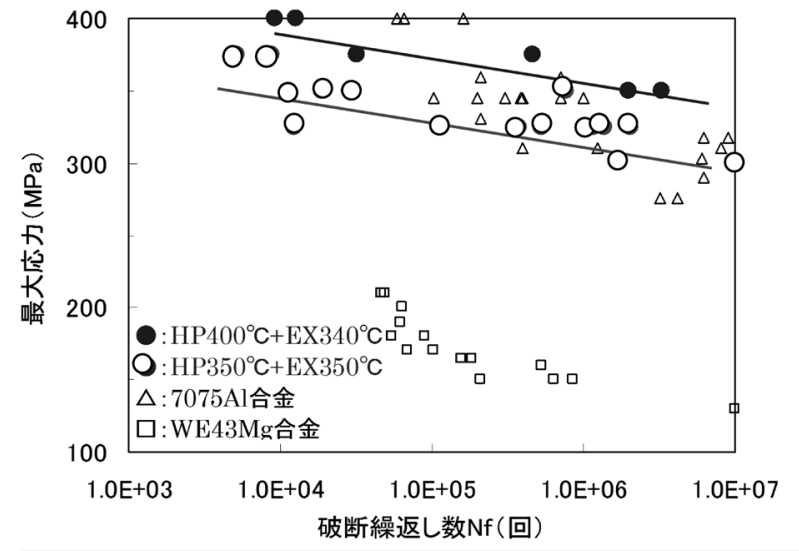

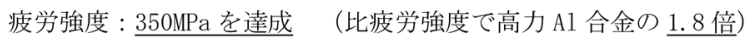

図11 マグネシウム粉末合金の疲労強度

上回り, 疲労強度も図 11 に示すように7075アルミニウム合 金材の 1.8 倍を示している。耐食性に関しては図12に示すよ うにFeが34 ppm 以下であれば，アルミニウム合金を上回る 耐食性を示し, 目標を達成している。また, 急冷薄片で製造 しているにもかかわらず, 異方性はほとんどない。最終的に は図 13 に示すようにZ型断面（幅 $33 \mathrm{~mm}$, 高さ $21 \mathrm{~mm}$, 厚さ 


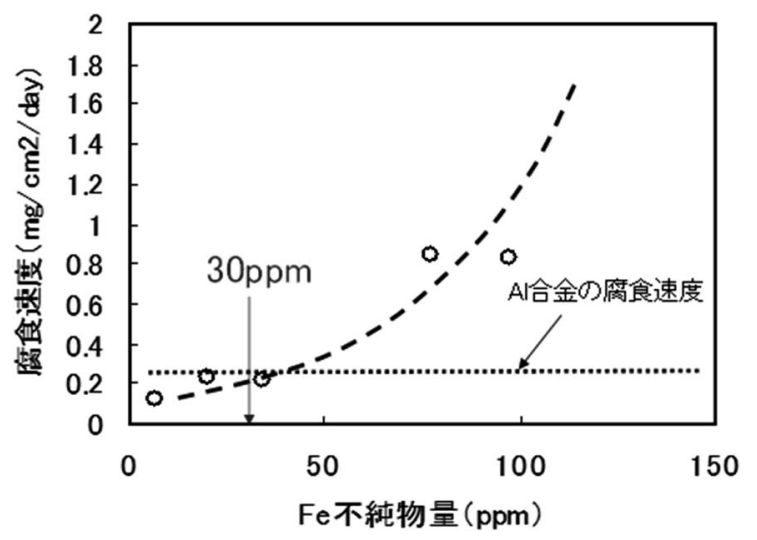

図 12 マグネシウム粉末合金の腐食試験結果

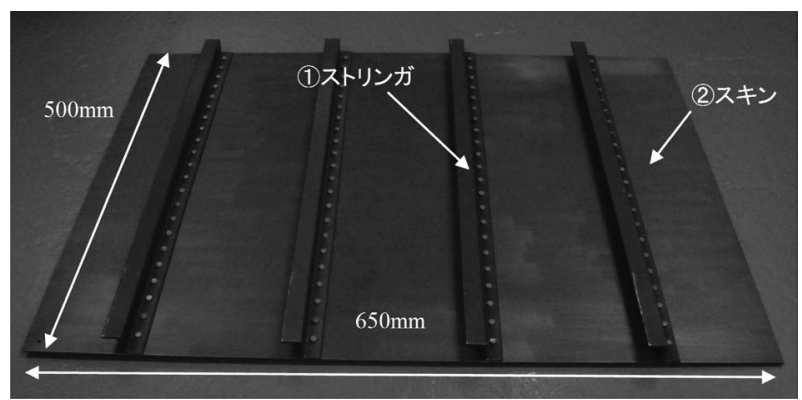

図13 マグネシウム粉末合金によるストリンガ試作品

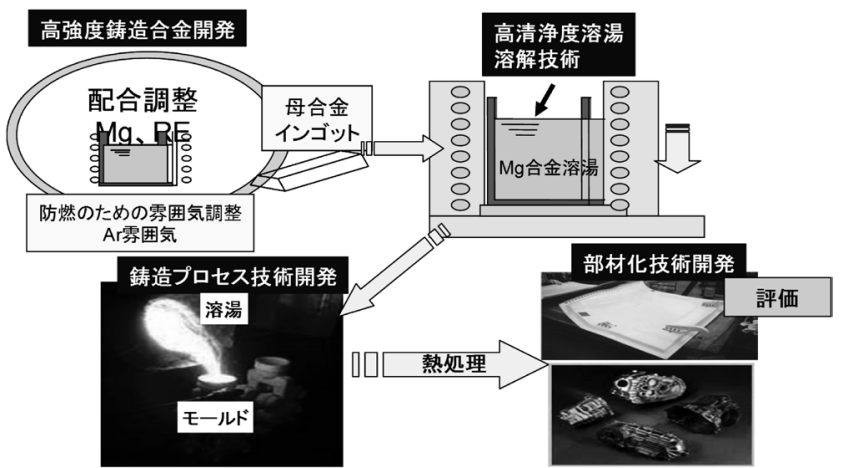

図14 マグネシウム鋳造合金製造プロセス

2〜3 mm）を持つストリンガを試作し，約 30\%の軽量化がで きることを実証した ${ }^{11)}$ 。

「次世代マグネシウム鋳造合金部材の開発」においてはア ルミニウム鋳造品の中で最も強度の高い $\mathrm{A} 201$ 材の 1.3 倍の比 強度および同等の耐食性を有する合金の開発を目標とした。 図 14 に製造プロセスを示すが，雲囲気中で溶解鋳造を連続 実施できる雲囲気溶解吸引鋳造プロセスを開発した。これに より溶湯の酸化による介在物の発生と巻き込みが抑制可能と なり，高品質な鋳物が作製できることとなった。結果として 図 15 に示すように $\mathrm{Mg}-3.2 \mathrm{Gd}-0.5 \mathrm{Zn}-0.2 \mathrm{Zr}$ 合金において強度 目標を達成した。耐食性は図16に示すようにA201合金に匹 敵する。試鋳した結果, 図 17 に示すように最小肉厚 $1.5 \mathrm{~mm}$ のリブ構造を有する薄肉箱形状鋳物の試作に成功した ${ }^{12)}$ 。 プロジェクト終了後も実用化に向けた検討が進められてい る。

また，河村らは熊本県とくまもとテクノ産業財団と共同
口達成強度 (平均値)

Mg-2.0Gd-1.2Y-0.75Zn-0.2Zr : 361MPa (T6のみ) $\mathrm{Mg}-3.2 \mathrm{Gd}-0.5 \mathrm{Zn}-0.2 \mathrm{Zr}$

413MPa (T6のみ)

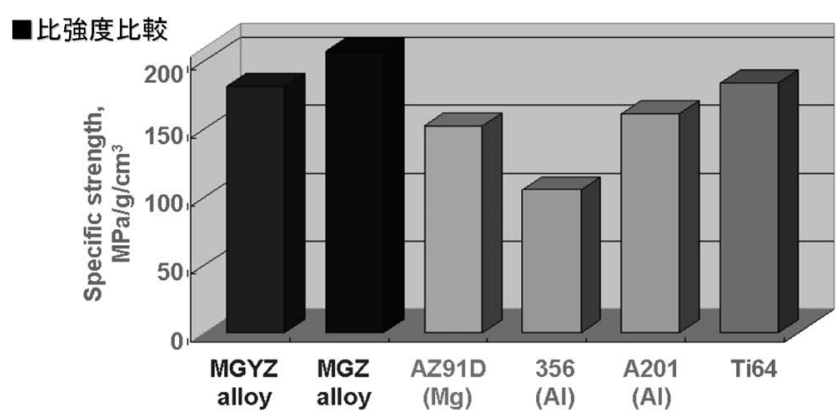

図15 マグネシウム鋳造合金比強度

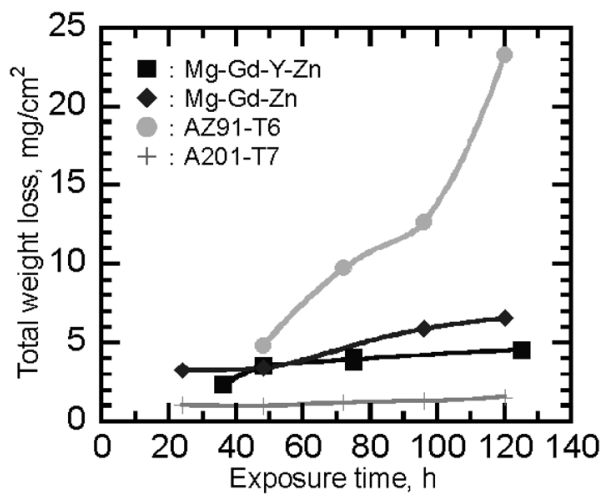

図16 マグネシウム鋳造合金腐食試験結果

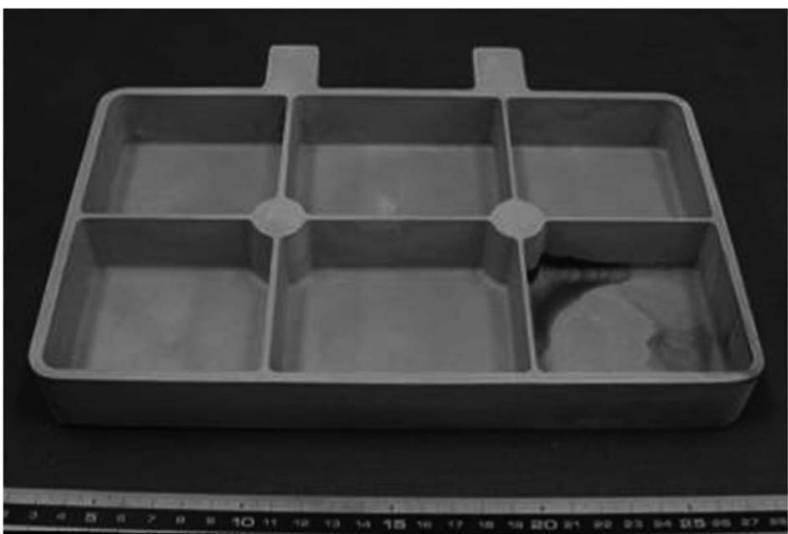

\begin{tabular}{|ll|}
\hline 外形 & $: 250 \times 150 \times 35 \mathrm{~mm}$ \\
外周・スキン板厚 & $: 4.5 \mathrm{~mm}$ \\
リブ板厚 & $: 1.5 \mathrm{~mm}$ \\
\hline
\end{tabular}

図17 マグネシウム鋳造合金試鋳品

で, 科学技術振興機構 (JST) の地域結集型研究開発プログ ラム（CREATE）「次世代耐熱マグネシウム合金の基盤技術 開発」を2006年〜2011年に実施し, LPSO型マグネシウム合 金の製造基盤技術の確立と「次世代耐熱マグネシウム合金実 用化プラットフォーム」の構築を図った ${ }^{9)}$ 。

2012 年にはマグネシウムの沸点 $\left(1091^{\circ} \mathrm{C}\right)$ を超えても発 火せず，しかも常温で $460 \mathrm{MPa}$ という引張降伏強さを持つ $\lceil K U M A D A I$ 不燃マグネシウム合金」を開発した。ちなみに LPSO 構造で強化した高強度・高耐熱性のマグネシウム合金 は「KUMADAI耐熱マグネシウム合金」と呼ばれることになっ 
た ${ }^{5)}$ 。

前述したように，FAAは所定の耐火試験に合格すること を条件に，マグネシウム合金の航空機機内部品への適用を 許可することになり，「KUMADAI不然マグネシウム合金」, $\lceil K U M A D A I$ 耐熱マグネシウム合金」とも試験をクリアして いる。

このような状況で, 2003 年から 2007 年まで実施した 「次世代航空機用構造部材創製・加工技術開発」で培った $K U M A D A I$ 耐熱マグネシウム合金の基盤技術を実用化につな げるべく，「次世代構造部材創製・加工技術開発」を 2013 年 から 2015 年の予定で立上げ「マグネシウム合金の開発と航 空機への適用研究」を国立大学法人熊本大学, 国立研究開発 法人宇宙航空研究開発機構, 三菱重工業株式会社, 富士重工 業株式会社が参加して実施中である。

ここでは，急冷凝固法および鋳造法で制作したKUMADAI 耐熱マグネシウム合金押出材の大型化と量産化のための基礎 技術確立を狙っている。表面処理やFSWによる接合方法に ついても検討を実施している。合せて圧延材として Mg-Li合 金の開発も実施している。

\section{6. おわりに}

2014 年 10 月には, 国立大学法人熊本大学と米国ボーイン グ社が急冷凝固法によるKUMADAI耐熱マグネシウム合金に

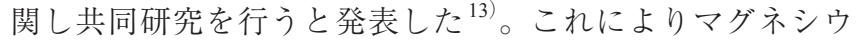
厶合金の航空機構造適用が大きく推進されると思われる。

今後は経済産業省, NEDO, 大学, 素材メーカ, 国内の航 空機メーカが連携してマグネシウム合金の航空機構造適用を めざし国内のサプライチェーン構築を図って行きたい。

\section{参 考 文 献}

1) 小原 久：航空と宇宙, 2007年3月号, (2007), 11-16.

2) 伊牟田守, 笹嶋幹雄 : 第 250 回塑性加工シンポジウム前刷り, 日本塑性加工学会, (2006), 35-42.

3) I. Ostrovsky and Y. Henn: International Conference-New Challenge in Aeronautics, ASTEC'07, (2007), 1-5.

4) 中田 守，小池 進：R\&D 神戸製鋼技報，50-3（2000），5861.

5) 河村能人：素形材, 55-6 (2014), 32-38.

6) 河村能人：アルトピア, 42-8 (2012), 9-13.

7) http://www.transport-research.info/web/projects/project_details. cfm?id=11198

8) http://www.transport-research.info/web/projects/project_details. $\mathrm{cfm} ? \mathrm{id}=35092$

9) http://magnesium-elektron.com

10) 河村能人, 大河内均, 関川貴洋, 関 義和：金属, $80(2010)$, 623-630.

11）都筑隆之：次世代航空機用構造部材創製・加工技術シンポジウ 厶講演集，(2008. 1)，37-42.

12）黑木康德：次世代航空機用構造部材創製・加工技術シンポジウ 么講演集，(2008. 1)， 31-35.

13) http://www.kumamoto-u.ac.jp/organizations/kico/news/20141110 